\title{
Land Administration and Authoritative Geospatial Information: Lessons from Disasters to Support Building Resilience to Pandemics
}

\author{
Keith Clifford Bell and Vladimir V. Evtimov
}

\begin{abstract}
Throughout 2020, much has been written advocating investment in geospatial information and land administration systems as solutions to pandemic resilience, but closer analyses may suggest a lack of rigor and even a tendency for hype. Resilience of countries, cities and communities in the context of land administration and geospatial information is best achieved through sustainable, authoritative, geospatial information under the framework of National Spatial Data Infrastructure (NSDI) and comprehensive and secure Land Administration Systems (LAS). However, it is becoming increasingly clear that the pandemic has severely impacted progress towards all the SDGs under the 2030 Agenda. Responding to disasters and pandemics does not afford the luxury of extended templated diagnostic assessments, economic and financial analyses and cost-benefit studies of investing in LAS and NSDI. Drawing on the experiences of the WB-FAO partnership, the Chapter discusses good practices of rapid assessments of the resilience and resilience impact of authoritative NSDI and LAS.
\end{abstract}

\section{$2.1 \quad$ Introduction}

"The COVID-19 crisis threatens to reverse much of the development progress made in recent years and throw hundreds of millions of people back into poverty. It has required countries to respond rapidly and decisively to major disruptions of their healthcare systems, their economies and the livelihoods of their citizens. I have been inspired by the World Bank Group's response - mobilizing fast to deliver urgent support to countries to minimize loss of life, mitigate severe economic hardship, protect hard-earned development gains, and protect the poorest and most vulnerable".

David Malpass, President of the World Bank. ${ }^{1}$

The COVID-19 pandemic has triggered the deepest global recession in decades, and this is well reported by both the World Bank [1] and the International Monetary Fund (IMF). This is the first recession since 1870 to be triggered solely by a pandemic. After more than a decade of uninterrupted growth, the global economy came to a sudden halt because of the pandemic. The debate continues as to how deep it will be; its duration; and how far its impacts will reach. The pandemic has

${ }^{1}$ World Bank President's end of year address to staff townhall, July 2, 2020. 
caused contractions across the vast majority of emerging market and developing economies as well as advanced economies. Lasting damage to labor productivity and potential output are already well identified. Across the world it would seem there is strong consensus for immediate policy priorities of alleviation of the human costs and attenuation of the short-term economic losses. Thereafter, once the crisis abates, there is also consensus that it will be necessary to reaffirm a credible commitment to policies to support long-term sustainable development. The COVID-19 recession's speed and depth with which it has struck suggests the possibility of a sluggish recovery. For many emerging market and developing countries, however, effective financial support and mitigation measures are particularly hard to achieve because a substantial share of employment is in informal sectors. The speed with which countries can overcome the pandemic health crisis and pave the way for economic recovery remains to be seen.

The COVID-19 pandemic is not the first global pandemic and it will not be the last, may almost be cliché now. Countries, especially low- and middle-income countries (LIC and MIC), are at the time of writing, fully focused on dealing with the severe health and economic crises. Generally, immediate priorities are budgetary support, health and food security. Beyond recovery, all nations, and development partners, must turn their respective foci to future preparedness to ensure that nations can better withstand the shocks of any future pandemic, with the impacts minimized to the greatest extent possible and recovery enabled in the shortest possible timeframe. However, no degree of preparedness can prevent future pandemics or disasters. Preparedness should include investment in land administration systems (LAS) and national spatial data infrastructures (NSDI).

The WB and the Food and Agriculture Organization (FAO) have partnered in many countries to promote the fundamental roles of LAS and NSDI to support the 2030 Agenda for Sustainable Development and also for improving disaster resilience at the national, city and community levels, in line with the Voluntary Guidelines on the Responsible Governance of Tenure (VGGT) [2] and the Sendai Framework for Disaster Risk Reduction 2015-30 [3].

\subsection{Emergencies - Disasters and Pandemics}

There are some similarities between the impacts of shocks created by a natural disaster and those created by disease - but only some. No country, regardless of its level of social and economic development is immune from the increasing frequency and severity of emergencies caused by disasters and pandemics. The World Health Organization ([4], p. 22) has prepared a very comprehensive Classification of Hazards, covering disasters, pandemics, conflicts and environmental degradation. From the disaster perspective it has consistency with the Sendai Framework, which sets out the case for all development to be risk-informed in order to be sustainable.

The Disaster Management Cycle, which originates from the United States Federal Emergency Management Agency (FEMA) ${ }^{2}$ is widely utilized. Over the past decade, the Disaster Management Cycle, has been interpreted, modified and adopted by many agencies around the world. Recently, with health crises, including the current pandemic, even WHO has adopted an equivalent 4-phase cycle [4] - Preparation, Response, Recovery and Mitigation. Understanding the cycle, enables a better appreciation of where geospatial information and land administration can be effectively applied in terms of response and building resilience, which is discussed later in this Chapter.

\subsection{Economic and Financial Impacts of Disasters and Pandemics}

Direct economic losses from disasters have increased by more than 150 percent over the past 20 years, with losses disproportionately borne by vulnerable developing countries. The bill from

\footnotetext{
${ }^{2}$ Noted by [5].
} 
natural disasters had reached around US\$200 billion per year, an increase of 4 times since the 1980s. However, it is estimated that this has now risen to around US $\$ 300$ billion per year. Cumulatively, over the past 30-year period, disasters have cost nearly US $\$ 4$ trillion and caused around 2.5 million deaths. Two-thirds of these losses are due to extreme storms, floods and drought [4].

WHO has advised that over the previous 30 years, more than 80 percent of deaths from natural disasters occurred in LIC and MIC and that the disaster impacts on GDP was on average 20 times higher in LIC than high-income countries (HIC). Further, and from the health perspective, WHO reported that during 2012-17, there were 1,200 health outbreaks in 168 countries, including those due to new or re-emerging infectious diseases. In 2018, a further 352 infectious disease events, including the Middle East respiratory syndrome coronavirus (MERS-CoV) and the Ebola virus disease. Estimated losses from infectious diseases, through their effects on productivity, trade and travel, have been calculated at about US $\$ 500$ billion or 6 percent of global income per year [4].

The WB [6] has identified critical impacts of the current pandemic. These are summarized as follows, with specific implications for land administration and geospatial information identified by the authors of this Chapter:

- Disrupting billions of lives and livelihoods, the COVID-19 pandemic threatens decades of hard-won development gains and demands an urgent, exceptional response. The severity of the pandemic is challenging the world's health systems, while associated lockdowns and travel restrictions have upended normal life for most people - even as lockdowns ease in some countries. The pandemic is spurring changes in behaviors and trends likely to transform the post-COVID-19 world. Lockdowns require resolving homelessness and unhealthy, crowded slums.

- The range of growth outcomes in 2020-21 remains exceptionally uncertain, and recovery is highly dependent on global progress in containing and mitigating the pandemic. In a base case scenario, the global economy could shrink by 5.2 percent in 2020 before rebounding in 2021 ; in the downside scenario of prolonged shutdowns, world output could contract by almost 8 percent in 2020 (roughly equivalent to the combined GDP of France, Italy, and Spain). The recession in advanced economies is hitting developing countries hard, and the WB now projects negative growth for over 150 countries in 2020. The emerging food crisis could intensify, and food insecurity could spread much more widely. Can governments afford to invest in LAS and NSDI to build resilience to future disaster and epidemic impacts? In the short-term, especially for LIC, the answer is likely to be no, without international development assistance.

- Billions of jobs are under threat worldwide. Nearly 80 percent of the world's informal economy workers, around 1.6 billion, have now experienced COVID-19 lockdowns and slowdowns in hard-hit industries including wholesale and retail, food and hospitality, tourism, transport and manufacturing. With 740 million women globally in informal employment and a majority employed in services, women are particularly hard hit by the crisis. Remittance flows are a key source of revenues for many developing economies, and expected to fall by one-fifth in 2020 . Tourism is another area hard hit. Many countries across East and South Asia are especially dependent on both tourism and remittances to a combined level of 20-30 percent of GDP. Loss of jobs places many people, renters and those with mortgages, at high risk of defaulting and subsequent eviction. Evictions create opportunities for property speculation and land grabbing, as well as governance challenges for land administration.

- The COVID-19 crisis is exacting a massive toll on the poor and vulnerable. Millions of people will fall into extreme poverty, while millions of existing poor will experience even deeper deprivation, the first increase in global poverty since 1998. This will mean an estimated additional 18 million extremely poor people in Fragile and Conflict-affected States (FCS), and the pandemic is deepening existing sources of fragility and exacerbating instability in Fragility, Conflict and Violence (FCV) settings. Land conflicts are major issues in FCS and can have long-term consequences as displaced people flee. Already the pandemic has manifested as a critical risk for refugee and resettlement camps. Homeless people are at high risk of contracting and spreading the virus and are not subjected to effective screening. Safe social distancing is 
largely not possible. Contact tracing of the homeless is also very difficult. Homelessness through eviction of insolvent renters is straining LIC, MIC and HIC alike.

- The scale of the financing challenge for developing countries is measured in trillions of US dollars. The sudden reversal of capital flows has helped finance the exceptional fiscal packages in the advanced economies but has left emerging market and developing economies exposed. The additional financing needs for developing countries arising from the crisis remain uncertain, but they will be exceptionally high and likely to persist over the medium term. Pandemic-related external financing gaps for active International Development Association (IDA) ${ }^{3}$ countries could be in the range of US $\$ 25-100$ billion per year - assuming that incremental financing needs arising from the crisis are in the range of 2-10 percent of GDP and that only half of these can be met internally. For WB International Bank for Reconstruction and Development $(\mathrm{IBRD})^{4}$ borrowers (representing approximately one-third of MIC GDP), the equivalent range is US\$150-600 billion annually. This has serious implications for countries needing financing of resilience requiring investments in LAS and NSDI.

The pandemic has highlighted the urgent need for policy action to cushion its consequences, protect vulnerable populations, and improve countries' capacity to cope with similar future events. It is also critical to address the challenges posed by informality and limited safety nets and undertake reforms that enable strong, inclusive and sustainable growth. However, the pandemic's rapid global economic impacts highlight the fragility of the sustainability of SDG Goal 1, extreme poverty alleviation [1].

\subsection{Overview of WB-FAO Partnership}

Since 1964, the Cooperative Programme (CP) between FAO and the WB has continued to support reforms concerned with secure access to land and other natural resources, reinforced national food security and nutrition, mainstreaming responsible land governance and sustainable economic development. Rapid penetration of innovative hi-tech geomatics accelerated digitalization of LAS and advancement of e-government have naturally expanded the FAO-WB investment partnership in the land sector to encompass NSDI. The body of experiences, good practices and lessons learned during such land sector investments supported by international development partners have duly informed, and are integrated in the VGGT. In general, poor tenure security, non-recognition of legitimate land rights and interests, or lack of land and geospatial records on access rights reduce the resilience of people to natural disasters and to climate change effects. Mindful of the resilience impact of LAS and NSDI, and triggered by various recent hazards, several joint interventions of the WB and FAO pay special attention to resilience building, and/or use resilience as an entry point for investing in land sector reforms.

The WB and FAO have partnered to promote the fundamental role of LAS and NSDI infrastructure for improving disaster resilience at the community and national levels, in line with the VGGT and the Sendai Framework. The recent CP experiences have highlighted good practice rapid assessments of the resilience and resilience impact of national land administration and geospatial information systems, which are relevant to the pandemic context, over several countries, which are discussed in this Chapter.

\footnotetext{
${ }^{3}$ IDA is part of the World Bank Group. IDA offers concessional loans and grants to the world's poorest developing countries.

${ }^{4}$ IBRD is part of the World Bank Group. The IBRD offers loans to middle-income developing countries.
} 


\subsection{Resilience Enablement Through LAS and NSDI}

Comprehensive and authoritative LAS and NSDI are of strategic importance for economic prosperity and inclusive growth, sustainable development, responsible governance of natural resources, and resilience - due to their potential to facilitate information synergy across multitudinous thematic domains and thus support efficient and effective decision making, as well as leveraging land as a fundamental economic factor and original source of all material wealth. In the context of national and community resilience, LAS and geospatial information are critically significant for systemic and institutional preparedness to enable the country, government and communities to mitigate hazards, adapt and recover from shocks or stresses. Such preparedness, adaption and recovery should be without compromising long-term development prospects of communities, cities, localities, regions and countries. That means digital information, secure data storage of land administration information and an NSDI providing geospatial information that is accessible, authoritative and sustainable. These are activities which must be led by the government for the benefit of all, with civil society, community, private sector professionals, investors and academic participation.

Resilience, be it for disasters or pandemics, requires a high degree of geospatial preparedness, which is best achieved through NSDI. For NSDI, countries require: (i) an agreed common geospatial framework with defined horizontal and vertical reference systems; (ii) standards, data sharing protocols and data access; (iii) fundamental mapping or geospatial datasets; (iv) an agreed lead agency mandate for the overall coordination of the NSDI and designated lead agencies for the production and maintenance of fundamental geospatial data themes; (v) communications; security; and (vi) human, technical and financial capacity to sustain the systems. In the context of a pandemic, further geospatial-related requirements may include: (i) access to mobility data from telecommunication networks, video-surveillance, urban and other sensors; (ii) tools to analyze the influx of near real-time data; (iii) spatially-enabled systems to support public health surveillance; and (iv) policies for balancing the protection of personal data privacy and confidentiality with ensuring the public good.

Many countries, especially LIC, may have very limited digital geospatial information and immature NSDI, limiting, or inhibiting, their preparedness for disasters or pandemics. For some LIC and MIC, recent wars or civil conflict have further left legacies of weak geospatial preparedness. Also, a legacy of conflict is often that LAS are either non-existent or in very poor shape due to the destruction of land records and other evidence of rights. For such countries, preparing any NSDI investment should be preceded by an assessment or stocktake of the existing systems. There is undoubtedly a geospatial preparedness inequity between countries, especially LIC, which places them at a severe disadvantage in developing resilience that requires geospatial information.

A major impediment to pandemic preparedness is often the weak street and postal addressing systems which precludes effective emergency response, contact tracing and monitoring of families and individuals for medical testing and follow-ups, vaccination programs, reliable reporting statistics, delivery and access to social benefits and so forth. For homeless people, even in advanced economies with well-developed address systems, the lack of access to an address is a major limitation and poses health risks especially where such people are mobile. Indigenous, customary and communal tenure systems are also especially vulnerable during pandemics where lack of formal records, geospatially referenced land parcels fabric and an addressing system leave inhabitants vulnerable.

As the world endures the pandemic and moves to the new norms, governments, often with international development assistance, will need to: (i) review how existing systems worked or failed during the pandemic; (ii) assess the effectiveness of geospatial information's and LAS contributions to surveillance and tracking; (iii) identify whether any non-traditional land and geospatial data sources (e.g. crowd-source data) may have government response to the pandemic; (iv) examine the effectiveness of measures used in the property markets, including valuation and government guarantee of tenure rights, addressing both ownership, leaseholds and rentals, to mitigate financial and economic downturns and ensure good governance; (v) review the impacts of land-indigence, 
landlessness and homelessness on the spread of the virus; (vi) study the impacts of regulated spatial planning on controlling the spread of the coronavirus and other future pandemics and health crises.

Authoritative geospatial information plays critical roles in all phases of disaster management: disaster prediction, prevention, preparedness and mitigation, emergency response, evacuation planning, search and rescue, shelter operations, and the post-disaster restoration and monitoring. Reliable and comprehensive land administration information, including land records are critical for many of the phases of disaster management including preparedness, recovery and reconstruction. Especially important for the pandemic context, is address information to enable reliable contact tracing and even social distancing. LAS and NSDI underpin economic and social recovering, supporting the minimization of the shocks of disasters and pandemics and enabling quicker recovery to return to normal.

Assessing the likely impact of disaster events requires detailed inventory of real estate assets, buildings, housing, crops, and infrastructure, including specific location-based information such as street address, and other horizontal and vertical positioning referencing data. Although, pandemics don't damage or destroy such items a spatial inventory of housing and occupancy would be expected to be beneficial.

Secure tenure is the key to reducing disaster vulnerability and risks. The more secure, formal and reconcilable the rights and systems are, the less vulnerable land users are to eviction or loss of livelihoods in the case of a disaster, and the more likely they are to receive compensation for losses sustained. Secure tenure increases investments in dwellings, which reduces risks and improves resilience through better siting and construction of buildings. Better quality housing in terms of space, ventilation, access, amongst other factors is conducive to supporting good social distancing and enhancing pandemic resilience.

Land administration and geospatial information needs to be accurate, reflect reality on the ground, and be up to date if it is to contribute to disaster preparedness and risk mitigation, and responses to disaster events. In many countries this is not the case, making them vulnerable to disasters. Street addressing transcends both land administration and geospatial information and is vital for both disaster and pandemic resilience.

Sharing land and geospatial information with disaster risk management agencies and enabling them to harness these valuable data in their planning and operations enhances the overall process and supports government-wide agendas, but often there are disconnects between a number of these key elements and a lack of interoperability. NSDI are essential to overcoming these issues. Improving interoperability means overcoming technical, capacity, legal, and cultural impediments.

LAS and NSDI can only perform their roles if they are themselves resilient - which means they must also be sustainable. Yet often LAS records are paper-based and are vulnerable to destruction. Remote storage of electronic data offers greater protection providing such data are properly secured. The organizations responsible for LAS and NSDI geospatial systems need to have business recovery plans which are regularly tested. These organizations need to be adequately resourced in terms of finances, trained personnel, equipment and facilities at all times. However, data must also be accessible. LAS and NSDI that are not able to deliver reliable, accessible information when there is no disaster or pandemic, cannot be expected to deliver during the times of disaster or pandemic.

Governance issues play an important role in the effectiveness of LAS and NSDI. Corrupt or ineffective town planning, land management, or building control systems enhance the risks from disaster events and impede recovery and reconstruction. Stakeholder involvement is needed so that all parties know the parts they must play in the event of a disaster event. Those responsible for disaster planning and mitigation and for reconstruction and recovery should be accountable to the population and respect human rights. Governance will be tested after any disaster. It is too early to assess any governance challenges from the COVID-19 pandemic, but in the near future such studies should be undertaken.

In light of the above, Table 2.1 summarizes applications for land administration and geospatial information in the emergency contexts of disasters and pandemics. 
TABLE 2.1

Land Administration and Geospatial Information Uses for Disasters and Pandemics

\begin{tabular}{|c|c|c|c|c|}
\hline \multirow{2}{*}{ 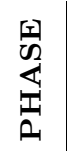 } & \multicolumn{2}{|c|}{ DISASTER } & \multicolumn{2}{|c|}{ PANDEMIC } \\
\hline & Geospatial & $\begin{array}{c}\text { Land } \\
\text { Administration }\end{array}$ & Geospatial & $\begin{array}{c}\text { Land } \\
\text { Administration }\end{array}$ \\
\hline 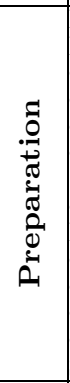 & \begin{tabular}{|l|} 
Needs assessment \\
Planning and response: \\
- evacuation \\
- communications \\
- medical support \\
- stockpiling resources \\
- location \\
Prediction \& Warning \\
- monitoring \\
- forecasting \\
- early warning \\
- exercising \\
Street addressing
\end{tabular} & $\begin{array}{l}\text { Spatial planning } \\
\text { Security of tenure } \\
\text { Security of records } \\
\text { Security of occupancy } \\
\text { Street addressing }\end{array}$ & $\begin{array}{l}\text { Needs assessment } \\
\text { Planning and response: } \\
\text { - evacuation } \\
\text { - communications } \\
\text { - medical support } \\
\text { - stockpiling resources location } \\
\text { Prediction \& Warning: } \\
\text { - monitoring } \\
\text { - forecasting } \\
\text { - early warning } \\
\text { - exercising } \\
\text { Street addressing }\end{array}$ & $\begin{array}{l}\text { Spatial planning } \\
\text { Security of tenure } \\
\text { Security of } \\
\text { occupancy } \\
\text { Street addressing } \\
\end{array}$ \\
\hline 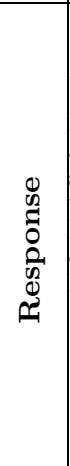 & $\begin{array}{l}\text { Coordination } \\
\text { Situation Analysis - } \\
\text { Appreciation } \\
\text { Crisis maps } \\
\text { Emergency aid - Search } \\
\text { and rescue, Evacuation \& } \\
\text { shelters, Medical, Food, } \\
\text { water } \\
\text { Emergency resources } \\
\text { dispatch } \\
\text { Early damage assessment }\end{array}$ & \begin{tabular}{|l|} 
Early damage assessment \\
$\mid$ \\
\end{tabular} & $\begin{array}{l}\text { Epidemiological surveillance } \\
\text { support systems } \\
\text { Contact tracing } \\
\text { Situation Analysis - } \\
\text { Appreciation } \\
\text { Pandemic mapping } \\
\text { Cases and deaths distribution, } \\
\text { monitoring } \\
\text { Testing coordination and } \\
\text { monitoring } \\
\text { Emergency resources dispatch } \\
\text { Streamlining supply chains - } \\
\text { delivery medical and food } \\
\text { Targeting community } \\
\text { investments to reduce risk of } \\
\text { contagion and minimizing } \\
\text { negative economic impacts }\end{array}$ & \\
\hline 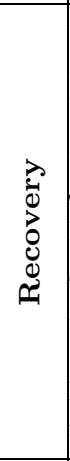 & \begin{tabular}{|l|} 
Recovery Reconstruction \\
Rehabilitation: \\
- coordination \\
- damage assessment \\
review \\
- monitoring and \\
evaluation \\
Tenure security location \\
Housing \\
Spatial Planning \\
Transport \& \\
infrastructure \\
Utilities \\
Communications and \\
ICT \\
Agriculture \\
Livelihoods
\end{tabular} & $\begin{array}{l}\text { Rights identification } \\
\text { Tenure security } \\
\text { Housing } \\
\text { Spatial Planning } \\
\text { Land re-allocation }\end{array}$ & \begin{tabular}{|l|} 
Epidemiological surveillance \\
support systems \\
Contact tracing \\
Pandemic mapping \\
Cases and deaths distribution, \\
monitoring \\
Testing coordination and \\
monitoring \\
Emergency resources dispatch \\
Streamlining supply chains -- \\
delivery medical and food \\
Targeting community \\
investments to reduce risk of \\
contagion and minimizing \\
negative economic impacts
\end{tabular} & $\begin{array}{l}\text { Spatial planning } \\
\text { Formalization of } \\
\text { rights }\end{array}$ \\
\hline 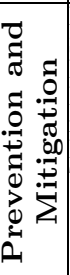 & $\begin{array}{l}\text { Hazard risk analysis } \\
\text { Simulation \& modelling } \\
\text { Risk mapping } \\
\text { Building \& asset } \\
\text { inventory } \\
\text { Public awareness raising } \\
\text { Training \& capacity } \\
\text { building }\end{array}$ & $\begin{array}{l}\text { Land records digitization } \\
\text { Data security } \\
\text { Secure, safe facilities } \\
\text { Online services } \\
\text { Spatial planning } \\
\text { Land re-allocation }\end{array}$ & $\begin{array}{l}\text { Spatial planning } \\
\text { Street addressing }\end{array}$ & $\begin{array}{l}\text { Spatial planning } \\
\text { Security of tenure }\end{array}$ \\
\hline
\end{tabular}




\subsection{COVID-19: Specific Challenges}

The pandemic has created land-tenure related and spatial challenges that have never been experienced before. These include, but are not limited to:

- Lockdown - requires a secure, serviceable, habitable place to live (dwelling) that is accessible to emergency services, power, water, sanitation. Homeless people and slum dwellers are especially at risk of contracting and spreading the virus

- Social distancing - sufficient space between people when they live and reside - again, homeless people and slum dwellers are especially at risk of contracting and spreading the virus

- Contact tracing - requires physical address - homeless people and slum dwellers are unlikely to have an address

- Privacy of personal information.

In response to the COVID-19 pandemic, many countries requested their citizens to practice social-distancing, stay-at-home and to stay safe. This has created significant challenges to implement, given the vast numbers of homeless people in both developed and developing nations. Also, for many countries housing conditions and density of informal settlements often do not allow residents to follow basic hygienic measures or to keep the minimum social distance to reduce spreading the virus. Much is being reported on the need to undertake "formalization or regularization of slums and illegal settlements". However, that may secure rights, but it does not improve safety, well-being, services, or quality of life.

Gender is also being reported as a specific COVID-19 challenge. Men have sustained a greater death toll from the pandemic than women. In April 2020, men accounted for 65 percent of deaths [7]. Stanley and Prettitore [8] specifically cite the gender experiences with tenure security of Aceh and North Sumatra following the December 2004 tsunami. It is well reported that in times of disasters and conflicts women may be especially vulnerable regarding tenure security and access to land rights [9]. In the longer term, reforming inheritance laws and marital property regimes will be key to improving the implementation and enforcement of women's rights to housing land and property rights, as well as ensuring that social and cultural norms also change. Titles or other rights instruments are not sufficient to bring about change and ensure the rights of women.

However, are women more vulnerable to the tenure-related shocks of the pandemic? Although Stanley and Prettitore [8] advise that women are more vulnerable, this Chapter suggests that it is probably far too soon to draw firm conclusions, but as more research and analysis is undertaken, it may also better highlight the vulnerabilities of women under a pandemic crisis. Nonetheless the tenure rights of everyone must be respected and the challenges are always there.

"Experience from post-disaster land activities in Aceh, Indonesia, and from post-conflict land restitution programs in Colombia have shown that with willingness and a focus on women's particular barriers, we can make a difference. It's time we break down the barriers to women's access to land around the world, and make sure to protect women's rights while the pandemic places them in a precarious situation" [8].

The United Nations Economic Commission for Europe (UNECE) Working Party on Land Administration and the International Federation of Surveyors (FIG) have admirably worked together to examine the situation of informal settlements in the pan-European region and have identified ways to formalize informal developments. The result has been the "Guidelines for the Formalization of Informal Constructions" [10], which provides a practical guide, explaining how to structure a program for the formalization of informal constructions. The Guidelines would seem to have the potential to be considered globally to assist countries in post-COVID-19 recovery. Benefits from formalizing informal settlements could contribute to economic recovery by integrating them into land markets, with clear ownership titles and registration. Security of tenure, ownership of land and property provides access to credit, and environmental, planning, construction, and utility-provision improvements can be initiated to a standard where people can live in adequate 
and healthy homes. The authors of this chapter would suggest that the Guidelines may have gone much further in terms of actual technical content especially regarding implications for construction, infrastructure service and utilities. Notwithstanding, these UNECE and FIG Guidelines are a useful reference for any country or jurisdiction seeking to address formalization of informal tenure. Commendably, UNECE has always been proactive when it comes to guidelines, especially in terms of improving land administration systems information in the region. Most notably, the UNECE [11] "Guidelines on Land Administration" have been referred to widely, not only in the European region, but globally.

It is well-reported that there are at least one billion urban dwellers currently living in informal settlements, which has increased from a 1996 estimate of around three-quarters of a billion. It will no doubt continue to grow as the world's urban population continues to grow. The importance of tackling this issue is undeniable and measured under several United Nations Sustainable Development Goals (SDGs). SDG target 1.4 stresses that governments should ensure that all men and women, particularly the poor and vulnerable, have equal rights to economic resources, as well as access to basic services, ownership and control over land and other forms of property and inheritance. SDG 11 stresses that cities and human settlements should be inclusive, safe, resilient and sustainable. The growth and magnitude of natural disasters around the world, of all types, have clearly identified the need for building resilience. Informal settlements have been built outside the formal system of laws and regulations that ensure tenure, legal ownership and safe, resilient structures. Informal development is not a new issue. However, over the last 30 years, informal development has become an increasingly urgent matter. UNECE reported in 2007 that more than 50 million people lived in informal settlements in 20 member-states of the UNECE region. Europe has experienced a rise of urban dwellers who cannot afford to pay rent, with housing costs rising particularly rapidly in the more prosperous large cities. This is especially the case for the Southern and Eastern parts of the region, while Western European countries are said to have more than 6 percent of their urban dwellers living in insecure housing conditions.

Slums are especially vulnerable due to:

- High population densities contribute to rapid and broader spread of infection which accelerates transmission

- Household overcrowding makes behaviors like social distancing difficult

- Poor living conditions exacerbate transmission slowing behavior

- Limited access to health services

- Reliance on crowded transport services increases contagion risk

- Working in the informal sector poses risks [12].

Renters, tenants, lessees and mortgagees are vulnerable to the economic impacts of the pandemic. All too often renters, tenants and lessees are forgotten in discussions of tenure security, as they do not hold absolute ownership rights. Rather, their tenure rights would be expected to be covered under contracts. However, often such tenure rights are not automatically inheritable, plus their security is generally subject to payment of rent, therefore they may be forfeited when rent payment defaults, leading to eviction. Similarly, mortgagees who are unable to defray mortgage repayments to the financier, may lose tenure rights and face foreclosure and eviction. Such problems are experienced globally, in both developed and developing economies. Notably some countries legislated relief periods for rents and mortgages - but periods of several months are already proving to be insufficient to people who have lost income and assets.

As the COVID-19 pandemic spreads across the globe, lives, livelihoods, food supplies and food security are being severely disrupted. In the face of this crisis, investment in agriculture and food systems provide an important way to support communities' resilience against crises and ensure robust food supply chains. This has very profound implication for land and tenure security as land is a critical factor in agriculture. Investment in the sector is crucial now more than ever, but experience shows that focusing only on more investments is not enough. The "Principles for Responsible Investment in Agriculture and Food Systems" (RAI) by the Committee on World Food Security 
[13] are the main global instrument to provide guidance in this regard. The RAI have heavily drawn from guiding frameworks such as the Principles for Responsible Agricultural Investment that respects rights, livelihoods, and resources (PRAI) by FAO, International Fund for Agricultural Development (IFAD), United Nations Conference on Trade and Development (UNCTAD), and the WB, and also build on the VGGT [14].

Location of citizens has been highlighted as a very important element of managing and responding to COVID-19 cases and transmissions. In public health, contact tracing has dual roles. Firstly, contact tracing is undertaken to find all infected persons and those who have been in contact with infected persons. It has been a very effective pillar of the control of communicable diseases, e.g. contact tracing was primarily responsible for small pox eradication, rather than universal immunization. Secondly, contact tracing may be undertaken to learn more about the disease characteristics, especially the spatial context including infection clusters, locations of secondary and subsequent infection waves/spikes. ${ }^{5}$ At the time of writing this Chapter, it has been reported that with the escalation of new cases in the USA, at around 50,000 new cases per day, contact tracing may no longer be viable. ${ }^{6}$

The pandemic has brought a global re-thinking of the confidentiality of personal information to better manage spread of the disease. Arguably, when the greater good is public health, new approaches to privacy of personal information are necessary. However, risks of abuse are being raised globally. In April 2020, the EU produced its "Commission Recommendation of 8.4.2020 on a common Union toolbox for the use of technology and data to combat and exit from the COVID-19 crisis, in particular concerning mobile applications and the use of anonymized mobility data". Also, in April 2020, the EU produced "Guidelines 04/2020 on the use of location data and contact tracing tools in the context of the COVID-19 outbreak". Both publications provide very useful guidance to any country or jurisdiction seeking to address personal information and also contact tracing through policy and regulatory means. Commendably, the EU has continued to be progressive in promoting sound policy with information and also NSDI. In 2007, the EU issued Directive 2007/2/EC for establishing an Infrastructure for Spatial Information in the European Community (INSPIRE). In 2016, the General Data Protection Regulation (EU)2016/679 (GDPR) was approved by the European Parliament as a regulation in EU law for data protection and privacy throughout the $\mathrm{EU}$, and member countries are required to comply.

In the COVID-19 context, vulnerable communities around the world are expected to face increased land grabs, migration, displacement, corruption, and evictions. For many countries, especially LIC and MIC, it is unlikely they have sufficient capacity and resources to fully address these challenges. Technology will undoubtedly play key roles, as already has been demonstrated with smart phone applications for contact tracing. At this time, there are many questions, and clarity may only come with time:

- Can LIC and MIC afford to fund LAS and NSDI investments at sufficient levels to rebound from the pandemic in order to return society to normal, when all countries have suffered huge economic losses?

- Articulating the benefits of funding land services, protecting the land claims of vulnerable populations, and accelerating the pace of securing land and property tenure is very important. Advocating for significant investments in technology, and ensuring political support to digital transformation at a time when there may be greater financial priories, is a huge challenge. How are we seeing technology and land data playing a role in COVID-19 planning and response and perhaps more importantly, what role can it play in post-pandemic response to better prepare us for the long-term?

- What successful technology-based approaches to land governance (including land administration, land development and land use planning) and lessons learned during COVID-19 can be continued? Evidence-based advocacy, rather than rhetoric and evidence from the land sector is required. Already there is an abundance of blogs, webinars and lobbying of governments and

\footnotetext{
${ }^{5}$ https://en.wikipedia.org/wiki/Contact-tracing

${ }^{6}$ https://www.docwirenews.com/docwire-pick/hem-onc-picks/the-covid-19-pandemic-close-to-12-millionworld-cases-contact-tracing-no-longer-possible-in-us-south-and-more/
} 
international finance institutions to fund technical interventions - often claiming pandemic recovery will be quicker through quickly deploying technologies that can be used to collect and manage land and geospatial data - such as smartphones, tablets, computers, handheld GPS/GNSS, and drones to name a few - how are they being used to equitably and inclusively accelerate land administration processes?

Building resilience, through sustainable LAS and NSDI requires investment - both for the development and implementation as well as ongoing maintenance, further development and continuous improvement. It very much should remind everyone why the word "infrastructure" was included in the term NSDI - which was to ensure that soft infrastructure is funded in a similar manner to hard infrastructure. The recession and financial challenges of governments around the globe, especially in LIC and MIC, creates opportunities for alternative service delivery including public-private partnerships (PPP). Bell [15] raised opportunities such as the provision of information technology (IT) infrastructure and services, positioning infrastructure and services including Continuously Operating Reference Stations (CORS) and customer service delivery as potential areas, subject to necessary safeguarding. Loss of capacity and governance concerns may also create openings for PPP modalities to support resilience investments in LAS and NSDI. However, any such investments, must be rigorously safeguarded by government oversight to ensure reliability, sustainability, good governance, public access and affordability.

\subsection{Pragmatic Rapid Assessment of LAS and NSDI Maturity in Resilience Contexts}

Countries cooperate with development partners to assess their respective land and geospatial information sectors and get advice on policy, legal, institutional, capacity and technology reforms aiming to boost sustainable socio-economic growth and natural resources management, enhance resilience to adversities, and safeguard the environment. The WB and FAO have frequently partnering through their $\mathrm{CP}$ to respond to such requests, promoting also the fundamental role of LAS and NSDI infrastructure for improving disaster resilience at the community and national levels, in line with the VGGT and the Sendai Framework. A rapid LAS and NSDI assessment approach has shaped up through the $\mathrm{CP}$ and collaboration with members and others, mostly driven by pragmatic considerations and restrictions imposed by funding modalities. The recent partnership experiences have highlighted good practice rapid assessments of the resilience and resilience impact of national land administration and geospatial information systems, over several countries including Nepal, Myanmar, Lebanon, Kyrgyzstan, and Uzbekistan. The same pragmatic rapid assessment approach was also used unilaterally by the WB in Kerala, Punjab, the Solomon Islands, Lao People's Democratic Republic (see Table 2.2). 


\section{TABLE 2.2}

Experiences with Pragmatic Rapid Assessment of LAS and NSDI Maturity in Resilience Contexts within Selected Countries

\begin{tabular}{|c|c|c|c|}
\hline 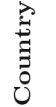 & Tailored focus & $\begin{array}{l}\text { Major findings in } \\
\text { resilience context }\end{array}$ & $\begin{array}{c}\text { Advantages / } \\
\text { benefits }\end{array}$ \\
\hline 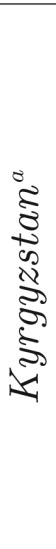 & $\begin{array}{l}\text { "Next generation land governance and } \\
\text { geospatial information services } \\
\quad>\text { building NSDI and geospatial data } \\
\text { and services } \\
\quad>\text { strengthening public land } \\
\text { management } \\
\quad>\text { strengthening property valuation } \\
\text { and taxation } \\
\quad>\text { strengthening land tenure and } \\
\text { access to encourage investment } \\
\text { " LAS and NSDI as a game- } \\
\text { changer for: } \\
\quad>\text { development } \\
\quad>\text { integrated planning, taxation, and } \\
\text { sustainable resource management } \\
>\text { disaster risk management (DRM) } \\
\quad>\text { climate resilience } \\
\quad>\text { private sector investment support }\end{array}$ & $\begin{array}{l}\text { \Hindrances for DRM / climate } \\
\text { resilience identified: } \\
\quad>\text { limited access due to } \\
\text { geospatial data secrecy } \\
\quad>\text { no obligation for data } \\
\text { sharing or exchange } \\
\quad>\text { shortage of authoritative } \\
\text { digital datasets } \\
\quad>\text { poor geospatial capacity } \\
\text { across stakeholders } \\
\quad>\text { departmental silo culture }\end{array}$ & $\begin{array}{l}\text { » highly participatory } \\
\text { » local trust / } \\
\text { consensus } \\
\text { » full country } \\
\text { ownership } \\
\text { » use national sources } \\
\text { » optimal speed } \\
\text { " affordability } \\
\text { "flexibility } \\
\text { » recommends strategy }\end{array}$ \\
\hline 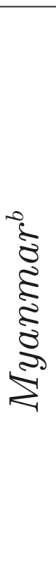 & $\begin{array}{l}\text { "Land sector needs assessment } \\
\quad>\text { land policy and regulatory } \\
\text { framework } \\
\quad>\text { forestland administration and } \\
\text { management } \\
\quad>\text { land administration } \\
\quad>\text { geospatial infrastructure and } \\
\text { services } \\
\quad>\text { property valuation and taxation } \\
\text { 'LAS and NSDI with core } \\
\text { geospatial datasets as a public } \\
\text { good underpin: } \\
\quad>\text { peace building } \\
>\text { food security } \\
>\text { poverty eradication } \\
>\text { sustainable economic development } \\
>\text { disaster and climate resilience } \\
>\text { land use policy implementation } \\
\quad>\text { e-governance advancement }\end{array}$ & $\begin{array}{l}\text { „Resilience suffers from } \\
\text { immature LAS and NSDI: } \\
\text { > relevant legal frame still } \\
\text { under development } \\
\quad>\text { One Map policy initiative } \\
\text { still not ripe } \\
\quad>\text { poor governance } \\
\text { informatization / digitalization } \\
>\text { wanting capacity, } \\
\text { technological innovation } \\
\quad>\text { restrictions on access to } \\
\text { geospatial data }\end{array}$ & $\begin{array}{l}\text { » highly participatory } \\
\text { » local trust / } \\
\text { consensus } \\
\text { » full country } \\
\text { ownership } \\
\text { » use national sources } \\
\text { » fits absorption } \\
\text { capacity } \\
\text { » monitoring } \\
\text { benchmark } \\
\text { » recommends strategy } \\
\text { "remedy problems } \\
\text { » realize opportunities } \\
\text { » pro-poor } \\
\text { "SDG achievement in } \\
\text { disaster risk reduction }\end{array}$ \\
\hline 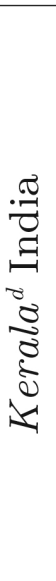 & $\begin{array}{l}\text { \Rebuild Kerala Initiative } \\
\text { targeting: } \\
\quad>\text { prepare better for future disasters } \\
\quad>\text { more resilient, green, inclusive and } \\
\text { vibrant vision for the future } \\
\quad>\text { generate revenue from property } \\
\text { taxation and value capture } \\
\quad>\text { prioritize resurvey and update of } \\
\text { land records } \\
\text { > unified on-line Land Information } \\
\text { Management System } \\
\quad>\text { interlinked digital databases }\end{array}$ & $\begin{array}{l}\text { \Weaknesses in the land and } \\
\text { geospatial systems exacerbated } \\
\text { the impact of natural disasters } \\
\quad>\text { missing right information at } \\
\text { the right time } \\
\quad>\text { unplanned land uses and } \\
\text { encroachments } \\
\quad>\text { fragmented, outdated, } \\
\text { inconsistent land records } \\
\quad>\text { outdated / historical paper } \\
\text { mapping } \\
\quad>\text { vulnerability of land records } \\
\text { to destruction } \\
\quad>\text { insufficient local revenue } \\
\text { from land } \\
\text { > Poor and social underclasses } \\
\text { are at serious risk from disasters } \\
\text { due to lack of formal rights and } \\
\text { poor spatial planning }\end{array}$ & $\begin{array}{l}\text { » highly participatory } \\
\text { » local trust / } \\
\text { consensus } \\
\text { » full state ownership } \\
\text { » use state sources } \\
\text { » optimal speed } \\
\text { » affordability } \\
\text { » fits absorption } \\
\text { capacity } \\
\text { »pro-poor } \\
\text { » recommends action }\end{array}$ \\
\hline
\end{tabular}




\section{TABLE 2.2}

Continued - Experiences with Pragmatic Rapid Assessment of LAS and NSDI Maturity in Resilience Contexts within Selected Countries

\begin{tabular}{|c|c|c|c|}
\hline 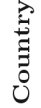 & Tailored focus & $\begin{array}{l}\text { Major findings in } \\
\text { resilience context }\end{array}$ & $\begin{array}{c}\text { Advantages / } \\
\text { benefits }\end{array}$ \\
\hline & $\begin{array}{l}\text { "Modernized, transparent and } \\
\text { resilient LAS and NSDI to } \\
\text { improve national and community } \\
\text { resilience to disasters } \\
\quad>\text { policy and legal framework for LAS } \\
\text { and NSDI } \\
\quad>\text { land registration and LAS } \\
\quad>N S D I \text { and related systems } \\
\quad>\text { land and property valuation } \\
\quad>\text { information and communications } \\
\text { technologies } \\
\quad>\text { education \& training for surveying, } \\
\text { geospatial sciences and LAS } \\
\quad>\text { social review }\end{array}$ & 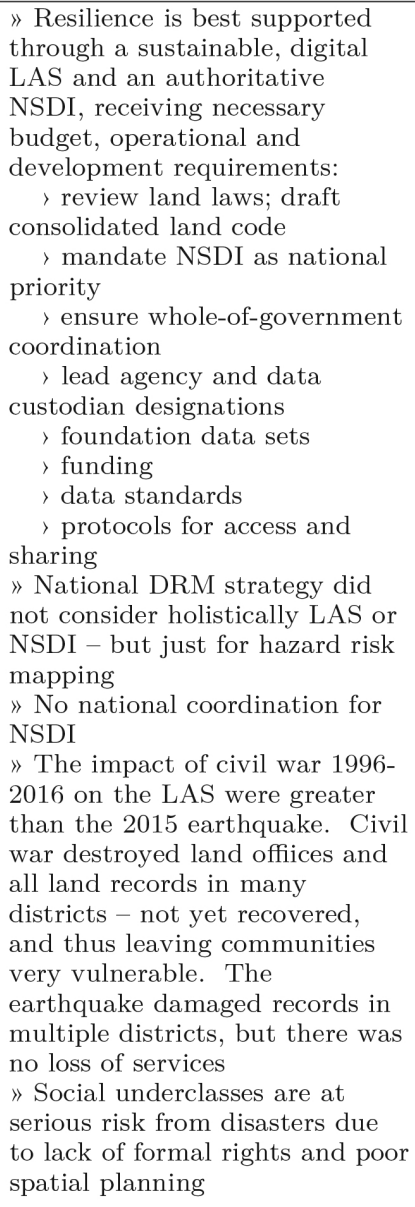 & 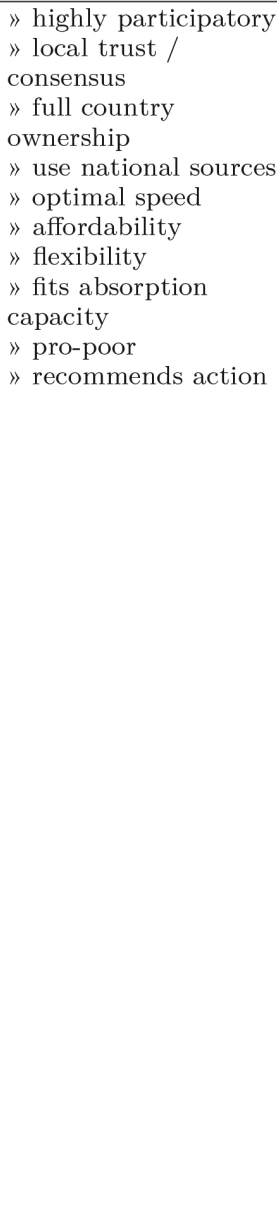 \\
\hline$\frac{\overrightarrow{0}}{\sqrt{\sigma}}$ & $\begin{array}{l}\text { \Build a unified land records } \\
\text { management system including } \\
\text { increased resilience to disasters needs } \\
\text { to: } \\
\quad>\text { assess legislation with consideration } \\
\text { of the resilience angle } \\
\quad>\text { assess disaster resilience with land } \\
\text { and geospatial systems }\end{array}$ & $\begin{array}{l}\text { \ To increase resilience to } \\
\text { disasters, one should: } \\
\quad>\text { improve community } \\
\text { resilience through enhancing } \\
\text { tenure security } \\
\quad>\text { leverage the use of } \\
\text { geospatial data } \\
\text { » Poor and social underclasses } \\
\text { are at serious risk from disasters } \\
\text { due to lack of formal rights and } \\
\text { poor spatial planning }\end{array}$ & $\begin{array}{l}\text { " participatory } \\
\text { " local trust / } \\
\text { consensus } \\
\text { " local ownership } \\
\text { " optimal speed } \\
\text { " affordability } \\
\text { " pro-poor } \\
\text { " recommends action }\end{array}$ \\
\hline
\end{tabular}


TABLE 2.2

Continued - Experiences with Pragmatic Rapid Assessment of LAS and NSDI Maturity in Resilience Contexts within Selected Countries

\begin{tabular}{|c|c|c|c|}
\hline 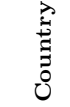 & Tailored focus & $\begin{array}{l}\text { Major findings in } \\
\text { resilience context }\end{array}$ & $\begin{array}{c}\text { Advantages / } \\
\text { benefits }\end{array}$ \\
\hline 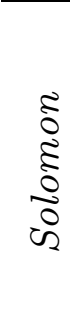 & $\begin{array}{l}\text { \Land and geospatial system } \\
\text { resilience needs assessment } \\
\quad \text { > diagnosis of LAS and geospatial } \\
\text { information system, their infrastructure } \\
\text { and resilience impact } \\
\quad \text { > design improvements for resilience } \\
\quad \text { > emphasise on access to land for } \\
\text { development } \\
\quad \text { > develop LAS and NSDI investment } \\
\text { plan }\end{array}$ & $\begin{array}{l}\text { » Resilience of land, real } \\
\text { property and the people to land } \\
\text { relationships requires: } \\
\quad>\text { community desire for better } \\
\text { land management } \\
\text { > register customary rights - } \\
\text { critical for resilience } \\
\text { > universal base map for all } \\
\text { the Solomon Islands } \\
\text { > share public geospatial } \\
\text { datasets via geoportal }\end{array}$ & $\begin{array}{l}\text { » participatory } \\
\text { l local trust / } \\
\text { consensus } \\
\text { » local ownership } \\
\text { optimal speed } \\
\text { » affordability } \\
\text { " recommends action }\end{array}$ \\
\hline$\overbrace{\substack{0 \\
0}}^{\substack{0 \\
0}}$ & $\begin{array}{l}\text { " Geospatial prioritization tool to: } \\
\text { > geographically target systematic } \\
\text { land registration } \\
\text { > determine geographical distribution } \\
\text { of natural disaster vulnerabilities and } \\
\text { tenure security risks } \\
\quad \text { > identify hotspots wherein } \\
\text { interventions can achieve maximum } \\
\text { impact } \\
\quad \text { support projects design and } \\
\text { implementation }\end{array}$ & $\begin{array}{l}\text { » Natural disaster } \\
\text { vulnerabilities must be a factor } \\
\text { in enhancing tenure security at } \\
\text { the local level, to: } \\
\quad>\text { ensure effectiveness and } \\
\text { efficiency } \\
\quad \text { > reaching those who need } \\
\text { tenure security most }\end{array}$ & $\begin{array}{l}\text { " participatory } \\
\text { local trust / } \\
\text { consensus } \\
\text { " local ownership } \\
\text { » optimal speed } \\
\text { " affordability } \\
\text { " recommends action }\end{array}$ \\
\hline \multicolumn{4}{|c|}{$\begin{array}{l}a \text { World Bank (2017) Kyrgyz Republic: Next Generation Land Administration and Management Services - non lending } \\
\text { technical assistance (P158348), Bishkek, } 2017\end{array}$} \\
\hline \multicolumn{4}{|c|}{$\begin{array}{l}b \text { World Bank (2018) Myanmar: Towards a Sustainable Land Administration and Management System - land sector } \\
\text { needs assessment technical assistance (P157559), Nay Pyi Taw, } 2018\end{array}$} \\
\hline \multicolumn{4}{|c|}{$\begin{array}{l}d \text { World Bank (2020) Solid Ground: Increasing community resilience through improved land administration and geospatial } \\
\text { geospatial information systems, Washington DC, 2020, p. } 33\end{array}$} \\
\hline \multicolumn{4}{|c|}{$e$ World Bank (2020) Nepal: Technical Assistance to Develop the Land Administration and Geospatial Information } \\
\hline \multicolumn{4}{|c|}{$\begin{array}{l}f \text { World Bank (2020) Improving Resilience and the Resilience Impact of National Land and Geospatial Systems - Phase II } \\
\text { implementation support, Washington DC, 2020, pp. 7-53 }\end{array}$} \\
\hline \multicolumn{4}{|c|}{$\begin{array}{l}g \text { World Bank (2020) Improving Resilience and the Resilience Impact of National Land and Geospatial Systems - Phase II } \\
\text { implementation support, Washington DC, 2020, pp. 54-87 }\end{array}$} \\
\hline \multicolumn{4}{|c|}{$\begin{array}{l}h \text { World Bank (2020) Improving Resilience and the Resilience Impact of National Land and Geospatial Systems - Phase II } \\
\text { implementation support, Washington DC, 2020, p. } 4\end{array}$} \\
\hline
\end{tabular}

The pragmatic rapid approach allows to produce targeted outputs within a short term (a couple of weeks) and with modest workload (around a man-month of expert input per topic). The approach relies on: strong ownership by, and participation of stakeholders - coupled with international expertise knowledgeable of good practices; ${ }^{7}$ expert analysis by brief desk review of web-sources, published documents, research, articles and statistics relying on local sources; gathering hands-on information in a limited series of face-to-face, profiling and cross-cutting technical discussions and field visits - during a short mission facilitated by the beneficiary; intensive home-based synthesis of outputs; and verification of findings and recommendations by key stakeholders. This good practice, - based on long-term WB and FAO expertise and experience - proves relevant and is appreciated by beneficiaries, since it is, among others: inherently focused on leaving no one behind, in line with good practices, ${ }^{8}$ and endeavoring to reach the furthest behind first; affordable; very adaptable to

\footnotetext{
${ }^{7}$ viz. VGGT and the Sendai Framework.

${ }^{8}$ Land-indigence refers to land holders whose land is: (i) too small or otherwise inadequate to support healthy living, social distancing during pandemics or other health crises; and/or (ii) insufficient for a livelihood in the context of rural small farmers.
} 
country specificity; participatory - thus capacitating in-country stakeholders; matching the needs - as its emphases, depth and detail can be tailored to the topical reform agenda; and producing outputs within tight time frames.

In assessing LAS and NSDI requirements the WB and FAO look at various tools to support and inform the work including a range of geomaturity and SDI-readiness ${ }^{9}$ instruments, considering and evaluating also other available tools for geomaturity and NSDI-readiness, including the Integrated Geospatial Information Framework (IGIF) developed under the United Nations Initiative on Global Geospatial Information Management (UN-GGIM). UN-GGIM is currently drafting a Framework for Effective Land Administration (FELA), as reference for developing, reforming, renewing, strengthening or modernizing land administration and management systems. Early discussions with selected WB client countries suggest that there are parallels with IGIF. That is, rather than implement another costly and time-consuming framework, simply consider its key elements during the rapid assessment. FAO has communicated its doubts regarding FELA's added value in the context of other existing UN instruments. Within WB, similar doubts are shared. Experience with IGIF's NSDI diagnostic, alignment to policy drivers, socio-economic assessment, and action planning, as piloted for example in Guyana ${ }^{10}$ (2018-19) - helps to draw parallels and inform the approaches elsewhere. However, after evaluation, it is often agreed with the governments that the pragmatic rapid approach is more suited to the resilience context especially as it is cheaper and quicker.

\subsection{Build Back Better}

Following a disaster event, it is not sufficient just for reconstruction to take place, but construction and land administration and geospatial information should be enhanced through building back better, so that there is greater resilience to future disaster events [1,6]. Disaster events often reoccur so that just undertaking recovery work is an inadequate response, as it is likely to be destroyed by the next disaster event. Only by building back better can communities be protected in the future. Investment in doing so produces substantial returns on the capital employed. Similarly, following a pandemic, building back better principles should also be adopted.

Rebuilding after disaster events requires reliable, accurate geospatial data, at the appropriate levels of precision to enable engineering and construction works to be undertaken, something that volunteer geographic information cannot achieve. Following the pandemic, reliable, accurate geospatial information is also required, especially to support rehabilitation of slums and areas of homelessness to ensure they are appropriately planned and serviced to ensure health and well-being.

From the historical perspective, the concept of "Build Back Better" (BBB) was probably first coined in Indonesia in 2005 in discussions between WB, the UN Special Envoy for Tsunami (Bill Clinton) and officials of the government's reconstruction agency (WB, 2005). ${ }^{11}$ The original concept was very much focused on physically building back better in terms of engineering of structures, assets and infrastructure, better planning, community safety, early warning as well as land rights, and gender equality. However, in the context of the pandemic, BBB has taken on broader roles including low carbon, climate change, green growth, the digital economy, addressing inequality, amongst other topics [16]. Investment in NSDI and LAS have much to contribute to this new view of BBB. Apropos SDGs 13 and 14, in the post-COVID-19 world, there is good reason to be optimistic that these and other long-standing global and regional issues will be addressed. LAS and NSDI have critical roles in contributing significantly to the solutions.

\footnotetext{
${ }^{9}$ Spatial-Data-Infrastructure readiness.

${ }^{10}$ FAO (2018), Mainstreaming Sustainable Land Development and Management in Guyana (project GCP/GUY/003/GRI).

${ }^{11}$ Attribution of this term's origin has been incorrectly attributed to the Sendai Framework, wherein it is reported that the term: "was firstly defined and used officially in the UN Sendai Framework for Disaster Risk Reduction 2015-2030, which was agreed at the Third UN World Conference on Disaster Risk Reduction 14-18 March 2015, which was held in Sendai Japan, and this document was adopted by the UN General Assembly on 3 June $2015 "$.
} 


\subsection{Concluding Remarks}

All countries, inter-governmental coordination bodies, development agencies, civil society organizations and professional bodies such as FIG have a role to play in promoting resilience through LAS and NSDI. The less hype and the more evidence-based approaches to support resilience, the better prepared communities will be to withstand the shocks of the next disaster or pandemic. Fit-for-purpose investments, that can be incrementally improved over time, which require sustainable LAS and NSDI, will enable resilience and ensure that legacy systems are not barriers to recovery after any shock. The partnership between the WB and FAO to promote the VGGT, will continue to play a leading global role in supporting the resilience of countries, cities and communities.

For the land sector, the outbreak again brings to light the very intimate, spatial relationships between land, people and communities - and how the shocks of any disaster or pandemic disrupts life and livelihoods.

The land sector can better promote the adaption of relevant technologies. There is evidence that fit-for-purpose approaches to land administration can reduce costs and promote greater transparency and accountability in the building of complete LAS, given the growing availability and reach of technologies that can be used to collect and manage data, - such as smartphones, tablets, computers, handheld GPS/GNSS, and drones to name a few. However, technology is never a solution, rather it is an enabler. Using technology to overcome development challenges is not a new phenomenon. This is particularly true in the land sector, where tools for collecting and managing data relating to land use and rights have advanced considerably in recent decades. In the post-pandemic recovery, technology is likely to prove even more critical for the collection and management of land-related data to advance land rights and tenure security for millions of people left out of formal land systems. Mere formalization of rights in over-populated, unhealthy slums, will not build resilience unless there is spatial planning.

For those working in international development, the pandemic has brought almost everything to a complete standstill. Development agency priorities are generally committed to the higher priorities of governments dealing with the economic meltdowns as well as addressing health demands and urgent needs for survival of society including food security. These priorities may see deferments of new investment projects for LAS and NSDI. Most land sector interventions take considerable time to implement and political will is paramount. The post-pandemic world presents opportunities for significant progress with carbon emission reduction, climate change, green growth and PROBLUE. LAS and NSDI have key roles to play in the resilience of the post-pandemic world by Building Back Better.

"Adversity has the effect of eliciting talents, which in prosperous circumstances would have lain dormant".

Horace, Latin Philosopher (65-8 BC).

\section{References}

[1] World Bank. Global Economic Prospects, A World Bank Group Flagship Report. Washington, D.C., 2020.

[2] FAO-CFS. Voluntary Guidelines on the Responsible Governance of Tenure of Land, Fisheries and Forests in the Context of National Food Security. Rome, Italy, 2012.

[3] UNDRR. Sendai framework for disaster risk reduction 2015-2030. United Nations Office for Disaster Risk Reduction. New York, 2015. 
[4] WHO. Health Emergency and Disaster Risk Management Framework, World Health Organization. Switzerland, 2019.

[5] Bell K.C. Post-Disaster Recovery and Reconstruction from an International Development Perspective: Impact and Challenges for Land and Geospatial Professionals, keynote presentation to the 78th FIG Working Week 2016, "Recovery from Disaster", Christchurch. New Zealand, 2016.

[6] World Bank. Saving Lives, Scaling-up Impact and Getting Back on Track: World Bank Group COVID-19 Crisis Response Approach Paper. Washington, D.C., 2020.

[7] World Bank. Gender Dimensions of the COVID-19 Pandemic, Policy Note. World Bank, Washington, D.C., 2020.

[8] V. Stanley and P. Prettitore. How COVID-19 puts Women's Housing, Land, and Property Rights at Risk, World Bank blog "Sustainable Cities". Washington, D.C., 2020. URL https://blogs. worldbank .org/sustainablecities/how-covid-19-puts-womens-housingland-and-property-rights-risk?CID=WBW_AL_BlogNotification_EN_EXT.

[9] World Bank Government of Japan and FAO. The Voluntary Guidelines and the World Bank: Increasing Women's Access to Land, Approaches that Work, A Good Practices Brief, Brief No. 1. World Bank, Washington, D.C., 2015.

[10] UNECE and FIG. Guidelines for the Formalization of Informal Constructions, Report No. ECE/HBP/196, a Joint Publication of the United Nations Economic Commission for Europe (UNECE) and the International Federation of Surveyors. New York, USA, 2020.

[11] UNECE. Land Administration Guidelines: With Special Reference to Countries in Transition, United Nations and Economic Commission for Europe. New York \& Geneva, 1996.

[12] World Bank. Global Responses to COVID 19 in Slums and Cities: Practices from around the World, GSG Urban Poverty and Housing, Working Document. Washington, D.C., 2020.

[13] FAO.CFS. Principles for Responsible Investment in Agriculture and Food Systems, Food and Agriculture Organization of the United Nations Committee on World Food Security. 2014.

[14] FAO. Ensuring Resilient Communities and Food Supply in the Face of the COVID-19 Pandemic with Investments Guided by the CFS-RAI. 2020. URL http://www.fao.org/inaction/responsible-agricultural-investments/news/detail/en/c/1279359/.

[15] Bell K.C. Global Experiences with Public Private Partnerships for Land Registry Services: A Critical Review, in Coordinates, Vol XV, Issue 11, November 2019, Vol XV, Issue 12, December 2019, Vol XVI, Issue 1. 2019 and 2020.

[16] Cliffe S. Building Back Better in the Response to COVID-19: Action on Political Cohesion, Climate Change, and Inequality, CIC blog. Center on International Cooperation, New York University, 2020. URL https://cic.nyu.edu/blog/building-back-better-COVID-19. 
$\Longrightarrow$ Taylor \& Francis Taylor \& Francis Group

http://taylorandfrancis.com 